\title{
ISOLASI DAN UJI AKTIVITAS ANTIMIKROBA BAKTERI ASAM LAKTAT (BAL) DARI YOGHURT DALAM MENGHAMBAT PERTUMBUHAN BAKTERI Escherichia coli DAN Salmonella typhi
}

\author{
Suryani M.F Situmeang, Musthari , Selamat Riadi \\ Politeknik Kesehatan Kemenkes RI Jurusan Analis Kesehatan Medan \\ Email : selamat.riadi.ssi.msi@gmail.com
}

\begin{abstract}
ABSTRAK
Yoghurt dikenal dan disukai sebagian masyarakat karena bila dikonsumsi: 1) dapat memperbaiki proses pencernaan protein dan lemak, 2) merangsang sekresi cairan yang diperlukan untuk proses pencernaan seperti air liur, cairan lambung, empedu dan pancreas serta 3) mengurangi timbulnya reaksi alergi terhadap laktosa. Keberadaan Bakteri Asam Laktat (BAL) pada yoghurt sebagai probiotik berpotensi dalam meningkatkan fungsi fisiologis usus, mikroflora usus yang berperan dalam mengoptimalkan kondisi kesehatan tubuh. Keberadaan bakteri probiotik dapat mencegah pertumbuhan bakteri patogen seperti Escherichia coli dan Salmonella typhi. Bakteri Escherichia coli merupakan penyebab penyakit diare, sedangkan Salmonella typhi merupakan bakteri patogen pada manusia yang menyebabkan penyakit tifus. Tujuan Penelitian ini untuk mengetahui kemampuan bakteri asam laktat yang diisolasi dari yoghurt dalam menghambat pertumbuhan bakteri Escherichia coli dan Salmonella typhi. Metode penelitian secara eksperimen, waktu penelitian dilaksanakan pada bulan Juni s/d September 2017 di laboratorium terpadu Poltekkes Kemenkes RI Jurusan Analis Kesehatan Medan. Jenis data adalah data primer yang diambil dari hasil uji Bakteri Asam Laktat terhadap bakteri patogen menentukan besarnya zona hambat dan diuji menggunakan uji Anova. Hasil penelitian zona hambat tertinggi pada isolat bakteri Sp4 dan Sp3 yaitu sebesar 1,36 cm dan dapat menekan pertumbuhan bakteri Escherichia coli, sedangkan zona hambat terbesar ditunjukkan oleh Isolat Sp4 yaitu sebesra 1,26 cm sehingga dapat dinyatakn dapat menekan pertumbuhan bakteri Salmonella typhi. Hasil ketahanan terhadap PH pada isolat bakteri Sp4 dapat tumbuh sebanyak 45 koloni pada PH3, sedangkan untuk variasi kadar garam isolat bakteri Sp3 dapat tumbuh sebanyak 88 koloni yang merupakan koloni tertinggi pada konsentrasi garam $0,5 \%$.
\end{abstract}

Kata Kunci : Yoghurt, Bakteri Escherichia coli, Salmonella typhi.

\section{ISOLATION AND ANTIMICROBIAL ACTIVITY OF LACTIC ACID BAKTERIA (BAL) FROM YOGHURT INHIBITION GROWTH of Escherichia coli and Salmonella typhi.}

\begin{abstract}
Yoghurt is known and liked by some people because when consumed: 1) can improve protein digestion process and fat, 2) stimulate secretion of fluid needed for digestion process like saliva, stomach fluid, bile and pancreas and 3) reduce allergic reaction to lactose. The presence of lactic acid bacteria (bal) in yoghurt as a probiotic has the potential to improve the physiological function of the intestine, intestinal microflora that play a role in optimizing the health condition of the body. The presence of probiotic bacteria can prevent the growth of pathogenic bacteria such as Escherichia coli and Salmonella typhi. Bacteria Escherichia coli is a cause of diarrheal diseases, while Salmonella typhi is a pathogenic bacteria in humans that cause typhoid. The purpose of this study to determine the ability of lactic acid bacteria isolated from yoghurt in inhibiting the growth of Escherichia coli and Salmonella typhi bacteria. Experimental research method, the time of research conducted on june to sunday 2017 at laboratorium poltekkes kemenkes RI Department of Health Analyst Medan. Types of data are primary data taken from lactic acid bacteria test results against pathogen bacteria determining the size of the inhibit zone and tested using anova test. The highest inhibition zone research results on sp4 and sp3 bacteria isolate is 1.36 $\mathrm{cm}$ and can suppress Escherichia coli bacteria growth, while the largest inhibition zone is indicated by sp4 isolate is $1.26 \mathrm{~cm}$ so it can be stated can suppress the growth of Salmonella typhi bacteria. The results of resistance to $\mathrm{ph}$ in bacterial isolate sp4 can grow as many as 45 colonies on ph3. While for the variation of
\end{abstract}


salt content of bacteria sp3 can grow as many as 88 colony which is the highest colony at salt concentration $0,5 \%$

\section{Keyword :Yoghurt, Escherichia coli Bacteria, Salmonella typhi}

\section{Pendahuluan}

Produk yoghurt telah dikenal has dan disukai sebagian masyarakat karena bila dikonsumsi: 1) dapat memperbaiki proses pencernaan protein dan lemak, 2) merangsang sekresi cairan yang diperlukan untuk proses pencernaan seperti air liur, cairan lambung, empedu dan pancreas serta 3) mengurangi timbulnya reaksi alergi terhadap laktosa (Roginsky, 1988).

Keberadaan BAL pada yoghurt yang mengandung Lactobacillusbulgaris dan Streptococcus thermophilus sebagai probiotik berpotensi dalam meningkatkan fungsi fisiologis usus, mikroflora usus yang berperan dalam mengoptimalkan kondisi kesehatan tubuh (Rahman et al., 2012). Keberadaan bakteri probiotik dapat mencegah pertumbuhan bakteri patogen seperti Salmonella sp. dan Escherichia coli (Usmiati dan Utami 2008). E. coli merupakan penyebab penyakit diare (Dwidjoseputro, 2005) sedangkan Salmonella typhi merupakan bakteri patogen pada manusia yang menyebabkan penyakit tifus (Pelczar dan Chan, 2005).

Mikroba yang tergolong bakteri asam laktat (BAL) mempunyai aktivitas mikrobial yang tinggi karena produk yang dihasilkannya seperti acidophilin yang dihasilkan oleh Lactobacillus acidophilus dan bulgarican oleh Lactobacillus bulgaricus, juga Bifidobacterium akan menghambat pertumbuhan bakteri patogen baik yang tergolong gram positif atau negatif, diantaranya Staphylococcus, Salmonella, Shigella dan Pseudomonas, yang dapat merusak permiabilitas membran sel dan akan berakhir dengan bocornya/rusaknya dinding sel sehingga berakibat keluarnya hemoglobin dari sel.

Efek antimikroba bakteri asam laktat ini disebabkan oleh pembentukan asam laktat dan asam asetat serta penurunan $\mathrm{pH}$ yang dihasilkan. Selain itu bakteri asam laktat juga menghasilkan senyawa-senyawa penghambat lain seperti hidrogen peroksida, diasetil, karbondioksida, reuterin dan bakteriosin (Vuyst \& Vandamme, 1994).

Bakteri asam laktat dapat diisolasi dari berbagai sumber antara lain dari susu hasil fermentasi, sayuran yang telah busuk dan dari saluran pencernaan ikan atau udang. Jini et al., (2011) berhasil mengisolasi bakteri asam laktat dari saluran pencernaan ikan air tawar yaitu genus Enterococcus dan Pediococcus. Hasil penelitian menunjukkan bahwa kedua genus bakteri ini berpotensi menghambat pertumbuhan Escherichia coli dan Salmonella typhii. Zona hambat yang dihasilkan oleh Enterococcus dan Pediococcus terhadap E. coli lebih tinggi dibandingkan dengan zona hambatnya terhadap S. typhii.

Penelitian ini bertujuan untuk mengetahui kemampuan bakteri asam laktat yang diisolasi dari yoghurt dalam menghambat pertumbuhan bakteri Eschericia coli dan Salmonella typhi.

\section{Bahan dan Metode}

Penelitian dilaksanakan di Laboratorium terpadu Politeknik Kesehatan Kemenkes RI Jln Jamin Ginting Km 11 Lauchi Medan, pada bulan Juni s/d September 2017.

Bahan yang dipakai pada penelitian ini adalah yoghurt yang dijual di Supermarket Kota Medan. Jenis data yang digunakan dalam penelitian ini adalah data primer yangdiperoleh dari hasil isolasi bakteri asam laktat dari Yoghurt dan Hasil uji daya hambat bakteri asam laktat terhadap bakteri Escherichia coli dan Salmonella typhi.

Metode pemeriksaan dilakukan secara isolasi bakteri asam laktat menggunakan media pertumbuhan dan reaksi bio kimia. Bakteri Asam laktat yang diuji terhadap bakteri Escherichia coli dan Salmonelle thypi dengan metode Kirby Bauer.

\section{Isolasi Bakteri Asam Laktat Yoghurt}

Sebanyak $10 \mathrm{ml}$ sampel yogurth dimasukkan ke dalam tabung reaksi steril. Dilakukan pengenceran berseri hingga $10^{-5}$. Sebanyak $0,1 \mathrm{ml}$ dari masing-masing tingkat pengenceran diinokulasikan ke media MRSA dengan metode cawan sebar. Kultur diinkubasi selama 48 jam pada suhu ruang $\left( \pm 28-30^{\circ} \mathrm{C}\right)$. Isolat bakteri yang tumbuh dengan variasi perbedaan morfologi menyangkut bentuk, warna, tepi dan elevasi koloni selanjutnya dikoleksi. Isolat kemudian ditumbuhkan kembali pada media yang sama hingga nanti diperoleh isolat murni.

\section{Karakterisasi dan Identifikasi Bakteri Asam Laktat}

Identifikasi bakteri dilakukan berdasarkan ciriciri dan karakter morfologis secara visual dan mikroskopis. Identifikasi isolat bakteri berdasarkan ciri-ciri awal tersebut dicocokkan dengan buku identifikasi Bergeys Manual of Determinative of Bacteriology. Pengamatan morfologi secara visual dilakukan dengan mengamati bentuk, tepi, elevasi dan warna koloni. 
Pengamatan morfologi sel dilakukan dengan cara pengecatan Gram, sehingga dapat diamati bentuk, penataan dan penggolongan bakteri.

\section{Uji Biokimia}

Pengamatan sifat biokimia mencakup uji sitrat, uji katabolisme gula, uji motilitas, uji gelatin dan uji katalase(Cappuccino \& Sherman 1983).

\section{Uji Ketahanan Isolat terhadap pH Rendah}

Pengujian dilakukan dengan menumbuhkan $1 \%$ kultur berumur 24 jam ke dalam media MRS broth yang sebelumnya telah dilakukan pengaturan $\mathrm{pH}$ yaitu 3,$0 ; 2,5$ dan 2,0. Selanjutnya diinkubasi selama 24 jam pada suhu $37^{\circ} \mathrm{C}$. Pada akhir inkubasi dilakukan perhitungan jumlah bakteri dengan metode total plate count pada media MRS agar.

\section{Uji Ketahanan Isolat terhadap Kadar Garam}

Pengujian dilakukan dengan menginokulasikan 1\% kultur berumur 24 jam ke dalam $5 \mathrm{~mL}$ media MRS broth dengan penambahan garam empedu dengan konsentrasi $0,5 \% ; 1,25 \% ; 2,5 \% ; 3,75 \%$ dan $5 \%$. Kemudian diinkubasi pada suhu ruang selama 24 jam. Pada awal dan akhir inkubasi dilakukan perhitungan jumlah bakteri dengan metode totalplate count pada MRS agar.

\section{Uji Antagonis Isolat Bakteri Asam Laktat dengan Bakteri Patogen}

Tabel 1. Karakteristik isolat bakteri asam laktat

\begin{tabular}{ccccc}
\hline Isolat & Warna koloni & Bentuk & Tepi & Elevasi \\
\hline sp1 & Krem & Circular & Entire & Flat \\
sp2 & Krem & Circular & Entire & Convex \\
sp3 & Kuning muda & Circular & Entire & Convex \\
sp4 & Putih kekuningan & Circular & Entire & Convex \\
\hline
\end{tabular}

Pada tabel 1 di atas diketahui bahwa isolat bakteri sp1. dan sp2. memiliki karakteristik warna krem. Sedangkan isolat bakteri sp3. berwarna kuning muda dan sp4. berwarna putih kekuningan. Isolat bakteri sp2, sp3 dan sp4 memiliki bentuk circular, tepi entire dan elevasi convex. Karakteristik yang membedakan dengan
Pada uji antagonis isolat bakteri digunakan media Mueller Hinton Agar. Suspensi bakteri patogen dengan kerapatan sel $10^{8} \mathrm{CFU}$ dioleskan pada permukaan media uji dengan menggunakan cotton bud steril. Sebanyak $10 \mu \mathrm{l}$ suspensi bakteri asam laktat diteteskan pada kertas cakram kosong (oxoid). Pengujian antagonis isolat dilakukan dengan uji cakram metode Kirby-Bauer (Lay, 1994). Kertas cakram uji diletakkan pada kedua sisi media yang telah diolesi bakteri patogen dengan jarak tanam 3,5 cm. Cawan uji diinkubasi pada suhu ruang selama 24 jam. Aktivitas antagonis bakteri ditunjukkan dengan terbentuknya zona hambat. Pengamatan dimulai dilakukan dari hari kedua sampai hari kelima setelah masa inkubasi. Zona hambat yang terbentuk selanjutnya diukur dan dicatat.

Data yang diperoleh disajikan dalam bentuk tabulasi data dan diukur berdasarkan lebar zone hambat. Data dianalisis dengan rancangan acak lengkap ANOVA. (Analisa Of Varian)

\section{Hasil dan Pembahasan.}

Dari hasil isolasi diperoleh 4 jenis isolat bakteri asam laktat kandidat probiotik yaitu sp1., sp2., sp3., dan sp4 dengan karakteristik seperti pada tabel 1. Perbedaan karakteristik awal berdasarkan warna koloni, tepi koloni, bentuk koloni dan elevasi koloni.

Tabel 2. Hasil pewarnaan Gram isolat bakteri asam laktat

\begin{tabular}{ccccc}
\hline Isolat & Gram positif & Gram negatif & Bentuk & Penataan \\
\hline sp1 & $\sqrt{ }$ & - & Basil & Mono, diplo, strepto \\
sp2 & $\sqrt{ }$ & - & Basil & Mono, diplo, strepto \\
sp3 & $\sqrt{ }$ & - & Kokus & Mono, diplo, strepto, \\
sp4 & $\sqrt{ }$ & - & Basil & Mono, diplo, strepto \\
\hline
\end{tabular}

Pada tabel 2 menunjukkan bahwa semua isolat bakteri asam laktat merupakan kelompok gram positif dengan variasi bentuk isolat yang terdiri dari basil dan kokus. Penataan sel yaitu mono, isolat bakteri sp1 adalah pada elevasi koloni. Elevasi koloni bakteri sp1 yaitu flat. Karakteristik makroskopis digunakan sebagai tahap awal dalam membedakan koloni bakteri. Karakteristik bakteri dilanjutkan dengan cara pegamatan mikroskopis melalui pewarnaan Gram (Tabel 2).

- 146

\section{dengan penataan mono, diplo dan strepto.}

diplo, strepto dan staphylo. Isolat bakteri sp1, sp2 dan sp3 memiliki karakteristik mikroskopis yang sama yaitu gram positif, bentuk basil 
Sedangkan isolat bakteri sp3, memiliki karakteristik mikroskopis yaitu gram positif, bentuk kokus dengan penataan mono, diplo dan strepto. Perbedaan karakteristik yang ditunjukkan menandakan perbedaan jenis isolat yang diperoleh (Gambar 1).

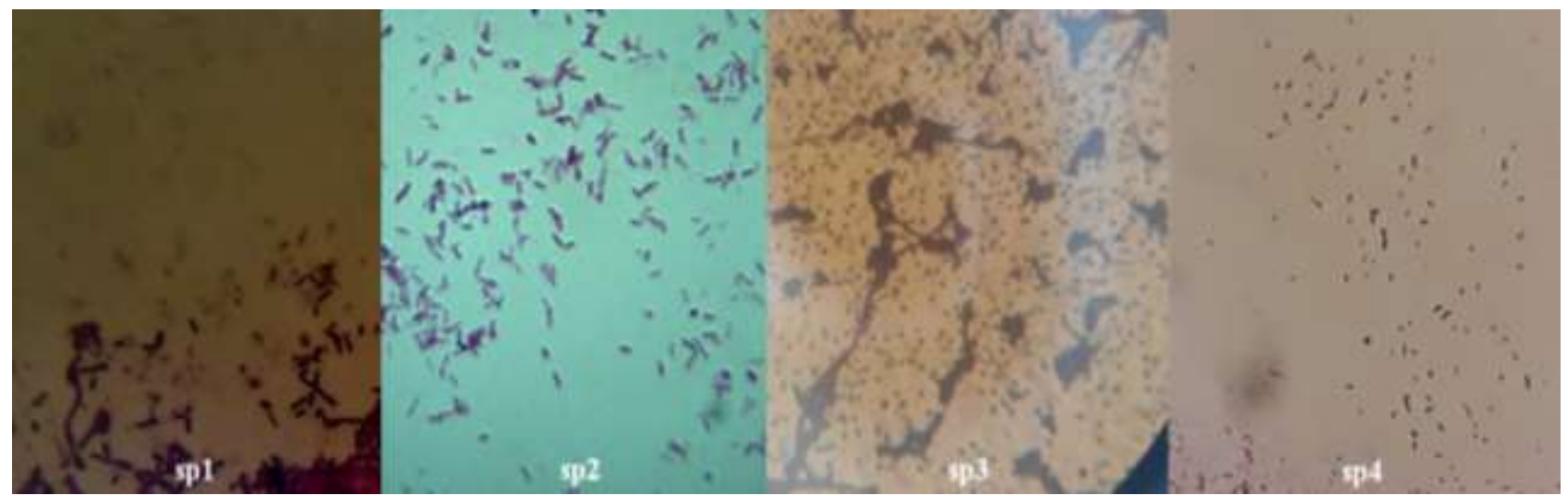

Gambar 1. Pewarnaan Gram isolat bakteri asam laktat (perbesaran 400 kali)

Pewarnaan gram merupakan teknik pewarnaan differensial yang paling penting dan paling luas digunakan untuk identifikasi bakteri. Bakteri yang diwarnai dengan metode gram ini dibagi menjadi dua kelompok, yaitu bakteri gram positif dan bakteri gram negatif. Bakteri gram negatif adalah bakteri yang tidak mempertahankan zat warna ungu pada pewarnaan gram. Sedangkan bakteri gram positif adalah bakteri yang akan mempertahankan warna ungu gelap setelah dibilas dengan alkohol (Lay, 1994).

Seluruh genus bakteri asam laktat diketahui merupakan kelompok bakteri gram positif. Sarkono et al (2010) mengisolasi bakteri asam laktat asal induk abalon dan mendapatkan 10 jenis isolat yang merupakan bakteri gram positif berbentuk basil. Hasil penelitian ini sejalan dengan Sujaya et al (2008) yang mengisolasi bakteri asam laktat dari susu kuda Sumbawa dan mendapatkan 35 isolat. Keseluruhan isolat merupakan bakteri gram positif dengan variasi bentuk basil panjang dan basil pendek. Identifikasi lanjutan yang dilakukan untuk memastikan kelompok bakteri asam laktat adalah uji biokimia (Tabel 3).

Tabel 3. Uji biokimia isolat bakteri asam laktat

\begin{tabular}{|c|c|c|c|c|}
\hline $\begin{array}{l}\text { Fermentasi } \\
\text { sitrat }\end{array}$ & Fermentasi gula & Motilitas & 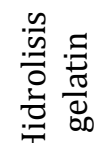 & $\begin{array}{c}\text { Enzim } \\
\text { katalase }\end{array}$ \\
\hline
\end{tabular}

\begin{tabular}{|c|c|c|c|c|c|}
\hline sp1 & + & + & + & - & - \\
\hline sp2 & + & + & + & - & - \\
\hline sp3 & + & + & + & - & + \\
\hline sp4 & + & + & + & - & - \\
\hline
\end{tabular}

Uji biokimia dilakukan untuk mengetahui sifat fisiologis bakteri. Berdasarkan uji biokimia yang dilakukan diketahui bahwa isolat bakteri sp1, sp2, sp3 dan sp4 positif dalam memfermentasi sitrat, gula dan melakukan jejak pergerakan bakteri (motilitas). Keempat isolat tidak menghasilkan enzim gelatinase untuk menghidrolisis gelatine. Isolat bakteri sp3 diketahui positif dalam uji katalase, hal ini mengindikasikan bahwa isolat sp3 mampu menguraiakan molekul hidrogen peroksida dengan bantuan enzim katalase. Uji positif katalase ditandai dengan terbentuknya gelembung pada isolat yang diujikan (Gambar 2). 


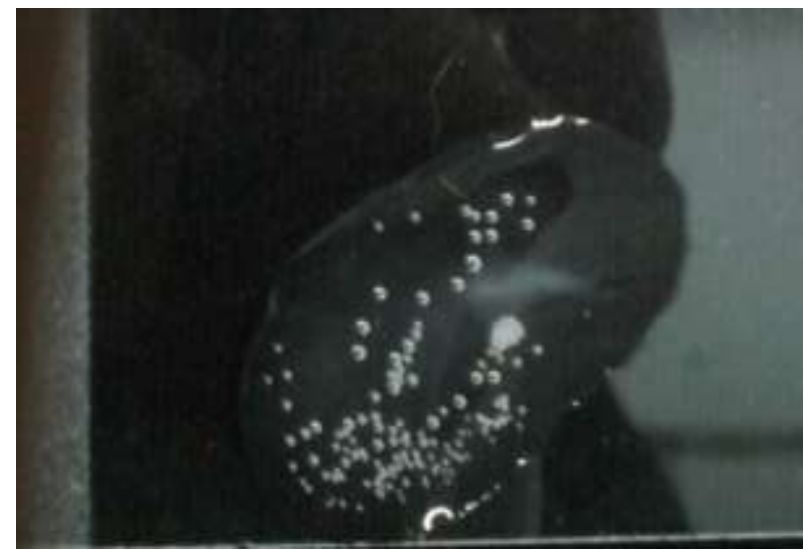

Gambar 2. Uji positif katalase pada isolat bakteri sp3

Bakteri asam laktat diketahui memiliki kemampuan hidup dalam kondisi asam. Pengujian fernentasi sitrat bertujuan untuk mengetahui kemampuan isolat bakteri dalam menggunakan sitrat sebagai satu - satunya sumber karbon. Jika bakteri mampu memfermentasikan sitrat, maka asam akan dihilangkan dari media uji. Perubahan pH akan menyebabkan perubahan warna media dari hijau menjadi biru.

\section{Kemampuan Antagonis Isolat Bakteri terhadap Escherichia coli}

Hasil uji antagonis isolat bakteri asam laktat terhadap bakteri patogen menunjukkan keempat isolat memiliki kemampuan yang berbeda-beda dalam menghambat pertumbuhan Escherichia coli. Kemampuan antagonis isolat ditandai dengan adanya zona hambat yang terbentuk pada daerah pertemuan koloni bakteri dengan bakteri patogen. Zona hambat yang terbentuk berupa cerukan penipisan elevasi (Gambar 3).

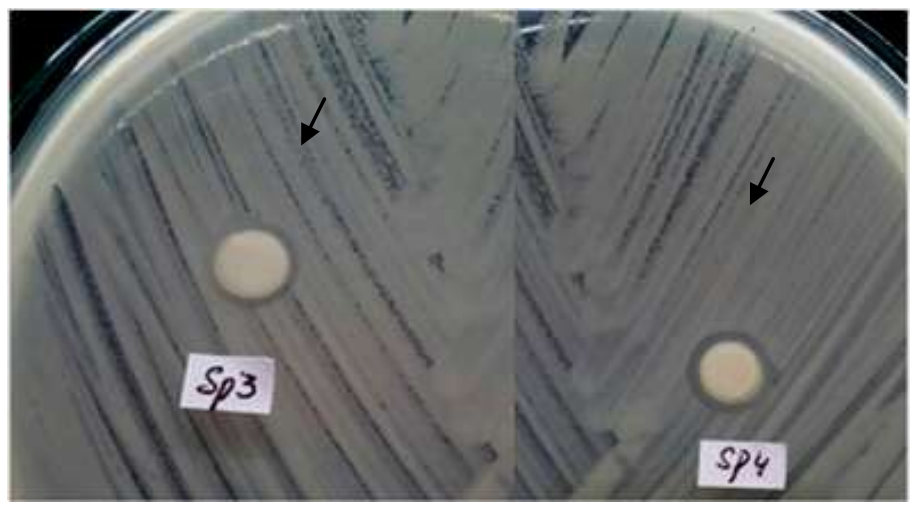

Gambar 3. Kemampuan antagonis isolat bakteri sp3 dan sp4 dalam menghambat pertumbuhan Escherichia coli

Zona hambat terbentuk karena adanya interaksi antara isolat bakteri asam laktat yang mendesak pertumbuhan Eschericia coli. Bakteri menghasilkan senyawa bioaktif yang dapat merusak komponen struktur dinding sel bakteri patogen. Adanya enzim hidrolitik yang dihasilkan oleh isolat bakteri asam laktat mampu mendegradasi komponen dinding sel bakteri patogen. Kemampuan antagonis bakteri asam laktat dalam menghambat pertumbuhan Eschericia coli ditandai dengan terhambatnya pertumbuhan bakteri tersebut dan pembentukan zona jernih di sekitar koloni bakteri patogen.

Perbedaan kemampuan masing-masing isolat bakteri asam laktat dalam menghambat pertumbuhan Escherichia col imungkin disebabkan perbedaan jenis senyawa aktif yang dihasilkan. Beberapa hal yang mempengaruhi besar kecilnya zona hambat yang dibentuk oleh isolat bakteri asam laktat terhadap Eschericia coliantara lain: interaksi antara kemampuan bakteri asam laktat dalam menghasilkan senyawa aktif atau enzim hidrolitik, umur biakan bakteri, jumlah senyawa aktif yang dihasilkan, komposisi medium dan waktu inkubasi. Penurunan zona hambat juga dapat terjadi karena isolat bakteri sudah masuk fase kematian disebabkan sumber nutrisi pada media terbatas(Dewi 2011).

Zona hambat dapat diamati pada hari kedua setelah masa inkubasi. Besarnya nilai zona hambat yang terbentuk dapat dilihat pada Tabel 4 . 
Tabel 4. Nilai zona hambat isolat bakteri asam laktat $(\mathrm{cm})$ terhadap bakteri Eschericia coli

\begin{tabular}{ccccccccc}
\hline \multirow{2}{*}{ Isolat } & \multicolumn{3}{c}{ Ulangan } & \multicolumn{3}{c}{ Total } & Rata2 \\
\cline { 2 - 8 } & I & II & III & IV & V & $\Sigma$ X & X \\
\cline { 2 - 8 } sp1 & 1 & 0.9 & 1.1 & 1 & 0.8 & 4.8 & 0.96 \\
sp2 & 0.7 & 0.8 & 0.8 & 0.9 & 0.8 & 4 & 0.8 & 1 \\
sp3 & 1 & 0.9 & 1.1 & 1.1 & 0.9 & 5 & 1.36 \\
sp4 & 1.2 & 1.4 & 1.5 & 1.4 & 1.3 & 6.8 & & \\
\hline
\end{tabular}

Zona hambat yang dibentuk setiap isolat bakteri asam laktat menunjukkan hasil yang berbeda - beda berkisar anatara $0.7-1.5 \mathrm{~cm}$. Hasil uji antagonis secara in vitro menunjukkan bahwa nilai rata - rata zona hambat tertinggi ditunjukkan oleh isolat bakteri sp4 yaitu sebesar $1.36 \mathrm{~cm}$. Sedangkan nilai rata - rata zona hambat terendah ditunjukkan oleh isolat bakteri sp2 yaitu sebesar $0.8 \mathrm{~cm}$.
Hasil uji ANOVA (Analisis of variance) menunjukkan bahwa isolat bakteri asam laktat berbeda nyata dalam menekan pertumbuhan Escherichia coli. Hasil uji lanjut DMRT (Duncan Multiple Range Test) dapat dilihat pada tabel dibawah ini.

Tabel 5. Hasil Uji DMRT isolat bakteri asam laktat terhadap Escherichia coli

\begin{tabular}{lll} 
& Rata $^{2}$ Perlakuan & \\
sp4 & 1.36 & A \\
sp3 & 1 & B \\
sp1 & 0.96 & C \\
sp2 & 0.8 & C \\
\hline
\end{tabular}

Uji Duncan isolat bakteri asam laktat terhadap diameter zona hambatbakteri Escherichia coliuntuk sp4 dan sp3 menunjukkan perbedan yang nyata ditandai dengan huruf yangberbeda. Hal ini berarti isolat bakteri asam laktat sp4 dan sp3 menunjukkan efek yang berbeda dalam menghambat pertumbuhan bakteri Escherichia coli. Sedangkan untuk isolat bakteri sp1 dan sp2 menunjukkan tidak ada perbedaan yang nyata terhadap zona hambat yang dihasilkan ditandai dengan huruf yang sama. Hal ini berarti isolat bakteri asam laktat sp1 dan sp2 menunjukkan efek yang sama dalam menghambat pertumbuhan bakteri Escherichia coli.

\section{Kemampuan Antagonis Isolat Bakteri terhadap Salmonella thypi}

Isolat bakteri asam laktat juga diujikan terhadap bakteri patogen Salmonella thypii. Bakteri Salmonella thypi juga merupakan patogen yang menyerang saluran pencernaan manusia. Kemampuan isolat bakteri asam laktat menghambat pertumbuhan bakteri Salmonella thypiditandai dengan adanya zona hambat yang terbentuk setelah masa inkubasi (Gambar 4).

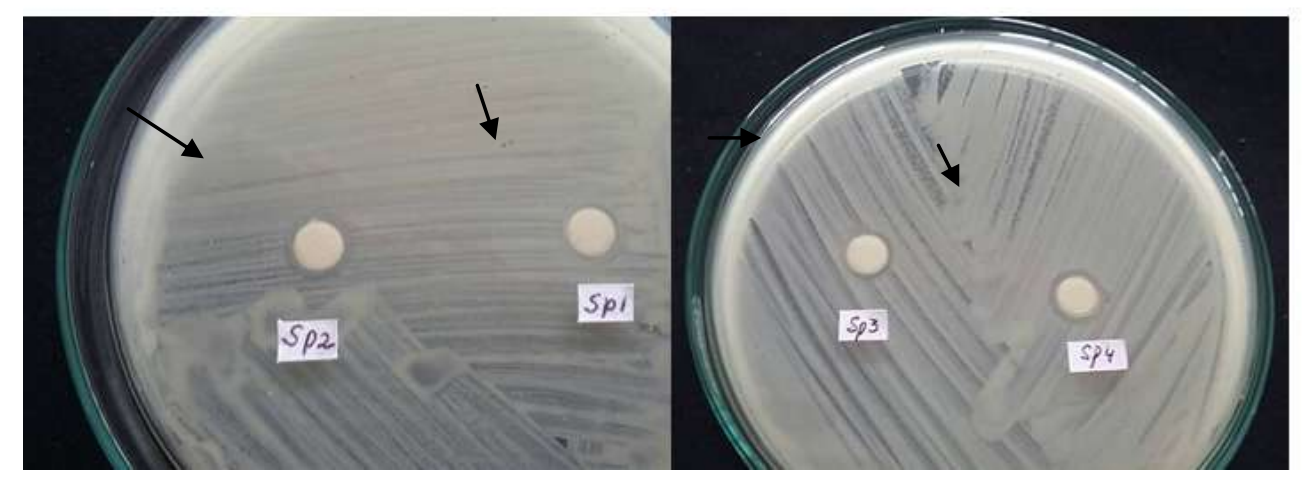

Gambar 4. Kemampuan antagonis isolat bakteri sp1, sp2, sp3 dan sp4 dalam menghambat pertumbuhan Salmonella thypi 
Kemampuan penghambatan isolat bakteri asam laktat ditandai dengan besaran zona hambat yang terbentuk. Zona hambat dihitung setelah hari kedua setelah masa inkubasi (Tabel 6).

Tabel 6. Nilai zona hambat isolat bakteri asam laktat $(\mathrm{cm})$ terhadap bakteri Salmonella thypi

\begin{tabular}{ccccccccc}
\hline & \multicolumn{3}{c}{ Ulangan } & \multicolumn{3}{c}{ Total } & \multicolumn{2}{c}{ Rata2 } \\
\cline { 2 - 8 } Isolat & I & II & III & IV & V & X & X \\
\cline { 2 - 8 } sp1 & 0.9 & 1.1 & 0.8 & 1.2 & 1.0 & 5.0 & 1.00 \\
sp2 & 1.0 & 1.0 & 0.8 & 0.9 & 1.0 & 4.7 & 0.94 \\
sp3 & 1.2 & 1.0 & 1.1 & 1.3 & 1.2 & 5.8 & 1.16 \\
sp4 & 1.1 & 1.3 & 1.2 & 1.4 & 1.3 & 6.3 & 1.26 \\
\hline
\end{tabular}

Pada tabel 6. menunjukkan data uji antagonis isolat bakteri asam laktat terhadap Salmonella thypi. Nilai rata - rata zona hambat terbesar ditunjukkan oleh bakteri asam laktat sp4 yaitu sebesar $1.26 \mathrm{~cm}$. Sedangkan nilai zona hambat terkecil ditunjukkan oleh bakteri asam laktat sp2 yaitu sebesar $0.94 \mathrm{~cm}$. Perbedaan nilai zona hambat yang terbentuk karena perbedaan jenis isolat.
Hasil uji ANOVA (Analisis of variance) menunjukkan bahwa isolat bakteri asam laktat berbeda nyata dalam menekan pertumbuhan Salmonella thypi. Hasil uji lanjut DMRT (Duncan Multiple Range Test) dapat dilihat pada tabel dibawah ini.

Tabel 7. Hasil Uji DMRT isolat bakteri asam laktat terhadap Salmonella thypi

\begin{tabular}{lrr} 
& Rata $^{2}$ Perlakuan & \\
\hline sp1 & 1.00 & B \\
sp2 & 0.94 & B \\
sp3 & 1.16 & A \\
sp4 & 1.26 & A \\
\hline
\end{tabular}

Uji Duncan isolat bakteri asam laktat terhadap diameter zona hambatbakteri Salmonella thypi untuk sp4 dan sp3 tidak menunjukkan perbedan yang nyata ditandai dengan huruf yang sama. Hal ini berarti isolat bakteri asam laktat sp4 dan sp3 menunjukkan efek yang sama dalam menghambat pertumbuhan bakteri Salmonella thypi. Jika kita lihat perbandingan efektifitas zona hambat antara isolat bakteri sp4 dan sp2 maka menunjukkan perbedaan yang nyata ditandai dengan munculnya notasi huruf yang berbeda. Sementara, perbendingan antara isolat bakteri sp1 dan $\mathrm{sp} 2$ menunjukkan tidak ada perbedaan yang nyata terhadap zona hambat yang dihasilkan ditandai dengan huruf yang sama. Hal ini berarti isolat bakteri asam laktat sp1 dan sp2 menunjukkan efek yang sama dalam menghambat pertumbuhan bakteri Salmonella thypi.

\section{Efektifitas Penghambatan Isolat terhadap Bakteri Patogen}

Efektifitas ditunjukkan oleh besaran zona hambat yang dihasilkan. Semakin besar zona hambat yang dihasilkan maka dapat disimpulkan bahwa isolat bakteri semakin efektif menghambat bakteri patogen Escherichia coli dan Salmonella thypi.

Perbandingan nilai zona hambat dapat dilihat pada Gambar 5. di bawah ini.

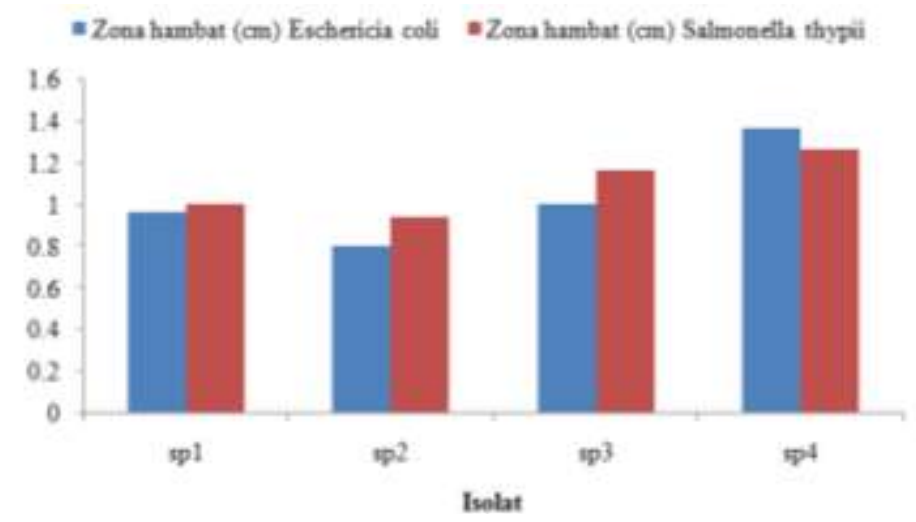

Gambar 5. Diagram batang perbandingan nilai zona hambat yang dihasilkan isolat bakteri asam laktat terhadap Escherichia coli dan Salmonella thypi. 
Keseluruhan isolat bakteri asam laktat mampu menghambat kedua jenis bakteri patogen, dengan besaran zona hambat yang berbeda - beda. Jika dilihat dari perbandingan histogram pada gambar 5, maka terlihat bahwa bakteri sp1, sp2 dan sp3 lebih efektif dalam menghambat pertumbuhan bakteri Salmonella thypi. Sementara bakteri sp4 lebih efektif dalam menghambat bakteri patogen Escherichia coli.

\section{Ketahanan Bakteri Asam Laktat terhadap pH dan Kadar Garam}

Kemampuan isolat bakteri asam laktat terhadap variasi $\mathrm{pH}$ dan kadar garam ditandai dengan jumlah total koloni yang tumbuh setelah masa inkubasi pada media dengan variasi $\mathrm{pH}$ dan kadar garam. Jumlah total koloni isolat bakteri asam laktat yang tumbuh dinyatakan dengan metode total plate count (Tabel 6).

Tabel 6. Pertumbuhan total bakteri pada variasi $\mathrm{pH}$ dan kadar garam

\begin{tabular}{|c|c|c|c|c|c|c|c|c|}
\hline \multirow{3}{*}{ Isolat } & \multicolumn{8}{|c|}{ Jumlah total bakteri (cfu) } \\
\hline & \multicolumn{3}{|c|}{ Variasi pH } & \multicolumn{5}{|c|}{ Variasi kadar garam (\%) } \\
\hline & 3.0 & 2.5 & 2.0 & $0.5 \%$ & $1.25 \%$ & $2.5 \%$ & $3.75 \%$ & $5 \%$ \\
\hline sp1 & 17 & 0 & 0 & 56 & 29 & 0 & 0 & 0 \\
\hline sp2 & 28 & 17 & 0 & 78 & 56 & 35 & 0 & 0 \\
\hline sp3 & 33 & 20 & 12 & 88 & 56 & 32 & 0 & 0 \\
\hline $\operatorname{sp} 4$ & 45 & 29 & 0 & 78 & 62 & 35 & 0 & 0 \\
\hline
\end{tabular}

Pada tabel 6 di atas diketahui bahwa variasi $\mathrm{pH}$ yang dapat ditoleransi oleh isolat bakteri berkisar antara 3.0 - 2.5. Isolat bakteri sp3 masih dapat hidup pada $\mathrm{pH} 2.0$ dengan jumlah total koloni yang tumbuh yaitu 12 koloni. Sedangkan isolat bakteri sp1 hanya mampu tumbuh pada pH 3.0 yaitu sebanyak 17 koloni. Variasi pH menandakan kemampuan isolat bakteri asam laktat hidup dalam kondisi asam.

Sedangkan variasi kadar garam dilakukan untuk memastikan apakah isolat bakteri asam laktat memang toleran terhadap kehadiran kadar garam. Berdasarkan pengujian yang dilakukan, isolat bakteri asam laktat toleran terhadap kehadiran garam $0.5 \%, 1.25 \%$ an $2.5 \%$. dapat dilihat dari jumlah total koloni yang tumbuh. Pada konsentrasi $0.5 \%$ jumlah koloni tertinggi yaitu sp3 sebanyak 88 koloni bakteri. Pada konsentrasi $1.25 \%$ jumlah total koloni tertinggi yaitu sp4 sebanyak 62 koloni bakteri. Pada konsentrasi 2.5\% jumlah total koloni tertinggi yaitu sp2 dan sp4 sebanyak 35 koloni bakteri. Keempat isolat bakteri asam laktat tidak mampu tumbuh pada konsentrasi kadar garam 3.75\% dan 5\%. Hal ini dikarenakan terlalu tingginya konsentrasi kadar garam tersebut, sehingga dapat menyebabkan plasmolisi pada sel bakteri.

\section{Kesimpulan}

Kesimpulan dari penelitian ini adalah diperoleh 4 jenis isolat bakteri asam laktat yaitu sp1, sp2, sp3 dan sp4. Seluruh isolat bakteri asam laktat diujikan memiliki kemampuan dalam menghambat pertumbuhan Escherichia coli dan Salmonella thypi. Isolat bakteri asam laktat sp4 merupakan isolat yang memiliki zona hambat terbesar terhadap Escherichia coli dan Salmonella thypi yaitu masing masing sebesar $1.36 \mathrm{~cm}$ dan $1.26 \mathrm{~cm}$. Isolat bakteri asam laktat sp2 merupakan isolat yang memiliki zona hambat terkecil terhadap Escherichia coli dan Salmonella thypi yaitu masing - masing sebesar 0.8 $\mathrm{cm}$ dan $0.94 \mathrm{~cm}$. Isolat bakteri asam laktat sp1, sp2 dan sp3 lebih efektif dalam menghambat pertumbuhan bakteri Salmonella thypi. Sementara bakteri sp4 lebih efektif dalam menghambat bakteri patogen Escherichia coli.

\section{Daftar Pustaka}

Besung INK. 2009. Pengaruh Pemberian Ekstrak Kunyit Pada Anak Babi yang Menderita Colibacillosis. UNUD Digita Library.

Cappucino JG \& Sherman N. 1996. Microbiology: A Laboratory Manual. $4^{\text {th }}$ Ed. AddisonWesley Publishing Company.

Condon, S. 1987. Responses of Lactic Acid Bacteria to Oxygen. FEMS. Microbiol. Rev. 46: 269280.

Dwidjoseputro D. 2005. Dasar-dasar Mikrobiologi. Jakarta: Djambatan.

Fardiaz S, Jenie BSL, Solihati A.1997. Isolasi dan Seleksi Bakteri Asam Laktat ya Antimikroba dari Sauerkraut. , Teknologi dan Industri Pangan

Frazier WC \& Westhoff DC. 1988. Fooc Microbiology 4th ed. Mc Graw Co. Ltd., New York.

Gildberg, A. Mikkelsen, Sandaker, E. and Ring, E. 1997. Probiotic Effect of Lactid Acid Bacteria in The Feed on Growth and Survival of Fry of Atlantic Cod (Gadus morhua) Hydrobiologia. Appl, Microbiology. 352: 279-285.

Ginns CA, Benham ML, Adams LM, Whithear KG, Bettelheim KA, Crabb BS \& Browning GF. 2000. Colonization o the Respiratory Tract by a Virulent Strain of Avian Escherichia 
coli Requires carriage of a Conjugatitive Plasmid. Infection and Immunity. 3(68):16-19.

Jawetz E, Melnick J \& Adelberg E. 2001. Mikrobiologi Kedokteran. Buku 1. Terjemahan Bagian Mikrobiologi Fakultas Kedokteran Universitas Airlangga. Jakarta: Penerbit Salemba Medika.

Jini R, Swapna HC, Rai AK, Vrinda R, Halami PM, Sachindra NM, Bhaskar N. 2011. Isolation and Characterization of Potential Lactic Acid Bacteria (LAB) from Freshwater Fish Processing Wastes for Application in Fermentative Utilisation of Fish Processing Waste. Brazilian Journal of Microbiology 42: 1516-1525.

Khuzaemah, S. 2005. Pengaruh Aras Serat Kasar Ransum terhadap Kecernaan Serat kasar, Protein kasar dan Energi Metabolis pada Itik Tegal Jantan. Semarang: Skripsi Fakultas Peternakan Universitas Diponegoro.

Kusumawati, N. 2000. Peranan Bakteri Asam Laktat dalam Menghambat Listeria monocytogenes pada Bahan Pangan. Jurnal teknologi pangan dan gizi. 1(1): 10-15.

Lay B. 1994. Analisa Mikroba di Laboratorium. PT. Raja Grafindo Persada. Jakarta.

Ngendaung S. 2001. Study on Bacterion-Producing Lactic Acid Bacteria from Fermented Foods. Master Thesis, Microbiology, Kasetsart university, Bangkok.

Noviana H. 2004. Isolasi dan Uji Kepekaan Isolat Klinis ORSA Dan Non ORSA Terhadap
Vankomisisn Dan Antibiotik Lainnya. J Mikrobiol Indonesia. 9(2): 51-54.

Pelczar JR \& Chan ECS. 2008. Dasar-dasar Mikrobiologi. Jakarta: UI-Press.

Rahman DH, Tanziha I, Usmiati S. 2012. Formulasi Produk Susu Fermentasi Kering dengan Penambahan Bakteri Probiotik Lactobacillus casei dan Bifidobacterium longum Jurnal Gizi dan Pangan 7(1):49-5.

Roginsky, H., 1988. Fermented milk. J. Dory Industrial Associafion of Auslralia: 163-169.

Saleh, E. 2004. Teknologi Pengolahan Susu dan Hasil Ikutan Ternak. Program Studi Produksi Ternak Fakultas Pertanian Universitas Sumatera Utara. USU Digital library.

Salminen, S., Ouwehand, A., Benno, Y. \& Lee Y.K. 1999. Probiotics: How Should Be Defined. Trends in Food Science and Technology. Vol.10: $107-110$.

Usmiati S, Utami T. 2008. Pengaruh Bakteri Probiotik terhadap Mutu Sari Kacang Tanah Fermentasi. Jurnal Pascapanen 5(2):27-36.

Vuyst, L. dan E.J. Vandamme. 1994. Antimicrobial potential of lactic acid bacteria In: De Vuyst, L. dan E.J. Vandamme. Bacteriocins of lactic acid bacteria: microbiology, genetic and application. London: Blackie Academic \& Professional.

Widodo, W. 2002. Bioteknologi Fermentasi Susu. Pusat Pengembangan Bioteknologi. Universitas Muhammadiyah Malang. 